ECONOMIC GROWTH CENTER

YALE UNIVERSITY

P.O. Box 208629

New Haven, CT 06520-8269

http://www.econ.yale.edu/ egcenter/

CENTER DISCUSSION PAPER NO. 915

\title{
Cross-Border Political Donations and Pareto-Efficient Tariffs
}

\author{
Masahiro Endoh \\ Yale University
}

June 2005

Notes: Center Discussion Papers are preliminary materials circulated to stimulate discussions and critical comments.

The author wishes to thank Koichi Hamada, T.N. Srinivasan, Paola Conconi, Eric Bond, Pravin Krishna, and Chia-Hui Lu for their helpful comments. Nevertheless, the author alone is responsible for any errors that appear in this paper.

This paper can be downloaded without charge from the Social Science Research Network electronic library at: http://ssrn.com/abstract $=756966$

An index to papers in the Economic Growth Center Discussion Paper Series is located at: http://www.econ.yale.edu/ egcenter/research.htm 


\title{
Cross-border Political Donations and Pareto-Efficient Tariffs *
}

\author{
Masahiro Endoh
}

\begin{abstract}
This paper examines the effects of lobbying activities across international borders, on determining each country's import tariff in a multi-principal, multi-agent, menu-auction model. Cross-border political donations could promote international policy cooperation because of two of their distinctive characteristics. First, special interest groups use cross-border donations as tools to wield their influence on ruling parties of other countries directly, which promotes efficiency of policy formation. Second, for ruling parties of countries, cross-border donations make them take into account the impact of their policy on other countries, which makes them more sensitive to other countries' welfare and, therefore, more cooperative with others. When ruling parties estimate the worth of political contributions from national special interest groups and from foreign lobbying groups with the same weight, Pareto-efficient tariffs are attained at which world welfare is maximized.
\end{abstract}

JEL Classifications: D72, F13, H21, P48

Keywords: Cross-border Donations, Truthful Equilibrium, Pareto-Efficient Tariffs.

* The author wishes to thank Koichi Hamada, T.N. Srinivasan, Paola Conconi, Eric Bond, Pravin Krishna, and Chia-Hui Lu for their helpful comments. Nevertheless, the author alone is responsible for any errors that appear in this paper. 


\section{Introduction}

Foreign donations to domestic political parties are generally considered to be harmful to a nation's independence. The climate of public opinion around the world with regard to cross-border political contributions is gradually but continuously strengthening to the point that would demand the delegitimization of accepting such donations. In fact, after the 1990's, some countries, such as Canada, the Czech Republic, the Russian Federation, the U.K. and Singapore, revised their regulations regarding political funding in order to prohibit national political parties from accepting contributions from foreign sources. In Canada, The Canada Elections Act was amended in 1993 to prohibit candidates and parties from receiving campaign contributions from abroad. In the U.K., The Political Parties, Elections and Referendums Act 2000 was enacted, aiming to regulate political donations, including a ban on foreign donations. The prevailing opinion among these countries is that foreign campaign contributions threaten their right to maintain their sovereignty, determine their own laws, and elect their own officials, free of outside interference. ${ }^{1}$

These negative circumstances for foreign political donations don't mean, however, that the topic is not worth considering. Rather, it is possible they could promote international policy cooperation in two ways. First, if the donors of political contributions are permitted to give donations to foreign countries, they could use their donations as tools to wield their influence on ruling parties of countries directly, which would promote efficiency of policy formation. Second, the ruling parties of countries, recipients of political contributions, would take into account the impact of their policy on other countries, which would make them more sensitive to other countries' welfare and, therefore, more cooperative with others. I explain these two benefits of cross-border political donations in this paper, taking import tariffs as an example. When ruling parties estimate the worth of political contributions from national special interest groups and from foreign lobbying groups with the same weight, Pareto-efficient tariffs are attained at which world welfare is maximized. This result implies that cross-border political contributions per se are not harmful for the formation of cooperative economic policies.

My economic analysis of political donations from abroad is inspired by two observations. First, two papers presented figures that show that foreign lobbying had a significant impact on the trade policy of the U.S. The pioneering work of Gawande, Krishna, and Robbins (2004) empirically demonstrated that in the years 1978 - 82, the presence of an organized non-U.S. lobby representing a particular industrial sector had as much effect on 
lowering tariffs against imports in that sector as did the presence of a U.S. lobby in raising tariffs there. Kee, Olarreaga, and Silva (2004) also showed that lobbying expenditures in the U.S. by Latin American exporters are a significant determinant of tariff preferences granted by the U.S. in the years $1997-2000 .^{2} \quad$ Seeing the positive effect of foreign lobbying activity on U.S. trade policy, it is natural to extend it to consider the case of "multilateral lobbying," that is, the combined case of domestic lobbying activities and two-way cross-border lobbying activities both from the home country to the foreign and from the foreign country to the home.

A second observation is that some scholars of international law found positive aspects of foreign donations in their research. Damrosch (1989) concludes that nonforcible political influence, including political funding which comes from foreign sources, has the potential both for enhancing internationally protected human rights and for promoting constructive, nonviolent relations between states, with the condition that it doesn't prevent the people of another state from exercising their political rights and freedoms. As for research focusing more on the economic aspect, Powell (1996) asserts that foreign corporations have a legitimate right to express their interests in some manner, since they have a significant interest in the domestic policies of other countries. He argues that the international community should direct its attention to attacking international bribery, instead of instituting blanket prohibitions against all types of foreign campaign contributions. My research complements these arguments from the point of view of economics, showing that foreign donations would make trade policies more cooperative internationally.

It is curious to see that the significance of foreign donations to domestic political parties has almost been neglected as a subject of economic research until recently, with the exception of Grossman and Helpman (1995) and Hamada (1993). Grossman and Helpman (1995) analyze in their appendix the conditions under which a free trade agreement could be concluded by two small countries in the case when politicians were permitted to accept donations from abroad. They found that the conditions in the case permitting cross-border donations could be more or less stringent than the conditions in the case prohibiting them, depending on the circumstances. Hamada (1993) considers the situation where one home lobby gave a political contribution in order that its home government would protect its profit, while one foreign lobby also donated to the home government in order to pressure it for free trade. In his setting, permitting a foreign donation would increase the national welfare of the home country. My paper extends Hamada (1993) in order to consider the effect of two-way lobbying across borders on import tariffs of two large countries in a general way by employing the theoretical foundation of Grossman and Helpman (1994).

Readers might consider my research target to be exceptional cases if we assume that the ban on accepting political donations from abroad is dominant in the world. In fact, 
political funding laws differ from country to country in their approach to foreign contributions. It is true that some large countries, the United States (U.S.), Canada, the United Kingdom (U.K.), France, and Japan, for example, have laws against foreign donations. There are, however, other countries that tolerate such donations explicitly or implicitly. Germany, the Scandinavian countries, Australia, and New Zealand, for example, permit their national parties to accept donations from abroad. Switzerland and Austria, proud of their permanent neutrality, admit foreign donations. According to Austin and Tjernström (2003), among 111 countries which are categorized as "free" and "partly free" concerning political rights and civil liberties in the 2002 Freedom House Index, and whose data are reported, only about one third (40 countries) have regulations totally banning political donations from foreign sources.

Table 1 classifies the number of countries which totally ban foreign donations by income and by region, reported in Austin and Tjernström (2003). This table shows that national income and per capita income of a country have little to do with whether that country admits or bans political donations from abroad. As for income, high national income countries and high per capita income countries don't necessarily totally ban political donations from abroad. Among 29 countries whose national GDP is more than 100,000 million US $\$$, fewer than half totally ban foreign donations, and among 28 countries whose GDP per capita is more than 10,000 US\$, only about two fifths do. As for regions, each of them has a significant number of countries which permit national parties to accept foreign contributions. Countries which tolerate foreign donations are neither exceptions nor symbols of underdevelopment. They are dispersed throughout the globe.

Previous achievements in economics provide us with tools to analyze this problem. I employ the notion of truthful strategy introduced by Bernheim and Whinston (1986). With the multi-principal, one-agent and first-price menu-auction model, under the assumption of complete information, they show that a truthful Nash equilibrium is always efficient and stable. Grossman and Helpman (1994) apply this equilibrium concept in a model of endogenous policy determination. Their reformulation of Bernheim and Whinston (1986) provides us a tractable way of thinking about the influence of lobbies on their government's policy decisions. The theoretical analysis of "multilateral lobbying" needs truthful strategy in a multi-principal multi-agent model, which was first proposed by Grossman and Helpman (1996) in a certain environment, and later by Prat and Rustichini (2003) in a more general case. The concept of weakly truthful equilibrium by Prat and Rustichini (2003) preserves the desirable characteristic of efficiency, which my results rely on. Although they don't consider strategic interdependency between agents, my model shows that, under certain circumstances, the efficient equilibrium is attained even under the existence of strategic relationships.

Various papers have investigated how to establish efficient trade policies and ensure 
freer trade, given the absence of a supra-national authority to enforce the terms of agreements concerning tariffs. Previous research is mainly divided into two groups. The first one examined the role of the General Agreement on Tariffs and Trade (GATT) and the World Trade Organization (WTO) to promote self-enforcing efficient tariff regimes. Dixit (1987), Bagwell and Staiger (1990), Riezman (1991), Maggi (1999) and Ederington (2001) treat GATT/WTO as a forum for repeating negotiation with the threat to retaliate for violation. Bagwell and Staiger (1999) evaluate the reciprocity principle of the GATT and find that it can assist governments in achieving efficient policy outcomes by eliminating the terms-of-trade effect of protection.

The second group looked at the noninstitutional interdependency of decision-making between economic activities as a tool to decrease tariffs endogenously. Devereux and Lee (1999) examine the interaction between international financial markets and trade policy, and find that free trade tends toward equilibrium when international financial markets are fully diversified. Krishna and Mitra (2005) discuss the idea that unilateral tariff reduction by a large country can induce a trading counterpart to reduce its tariff in return, with the model of endogenous lobby formation. Blanchard (2005) shows that export-platform foreign direct investment (FDI) induces unilateral tariff liberalization by the FDI-source country, suggesting that international capital mobility may substitute for multilateral trade liberalization. Limão (2005) analyses the linkage of retaliation between trade policy and environmental policy, and shows that if they are strategic complements then policy linkage can sustain more cooperation in both issues than no-linkage. This paper belongs to this group; I propose "multilateral lobbying" as a new tool to attain Pareto-efficient tariffs. Using multilateral lobbying the conditions for Pareto-efficiency are clear and simple.

The organization of this paper is as follows: Section 2 presents the basic economic structure of two countries involved in trade with each other. Section 3 considers domestic lobbying activities by national special interest groups, which propose their schedule of donations to the national ruling party. Section 4 takes cross-border lobbying activities into account additionally in the model. Section 5 examines the conditions in which the permission of both kinds of lobbying leads the economy to Pareto-efficiency and the sum of the two countries' welfare is maximized. Section 6 extends the model to the case of nonpecuniary negative externality. Finally, Section 7 concludes the paper and presents policy implication.

\section{The Model}

Consider a two-country multi-good general equilibrium model of trade. Two countries, home (no *) and foreign (*), produce and trade competitively $N+1$ goods. ${ }^{3}$ Good $O$ is a numeraire good, which is traded freely across countries and serves to settle the balance of trade. 
Numeraire good $O$ is produced by labor alone, with constant returns to scale. I choose units so that a world and domestic price of good $O$ is equal to one. It is assumed that aggregate labor supply, $L$, is large enough to sustain a positive output of good $O$. This implies that wage rates in numeraire terms are equalized to one across countries.

Each of the non-numeraire goods $i=1,2, \ldots, N$ is produced by labor and a sector-specific input, with constant returns to scale. Specific inputs are available in inelastic supply. Ruling parties (RPs) in the home and foreign countries use a vector of specific import tariffs $\tau=\left(\tau_{1}, \ldots, \tau_{N}\right)$ as a policy instrument. The local price of good $i$ in terms of the numeraire good $O$ is thus given by $p_{i}=p_{i w}+\tau_{i}$, where $p_{i w}$ is the world price ${ }^{4}$ With a wage rate equal to one, the total rent $R_{i}$ accruing to the specific factor in sector $i$ depends only on the local price of the good, and thus can be expressed as $R_{i}\left(p_{i}\right)$. Industry supply is then given by $Y_{i}\left(p_{i}\right)=\partial R_{i} / \partial p_{i}$.

The country is populated by a number of $H$ individuals, who have identical preferences with their utility functions taking the following form:

$$
u\left(c_{0}, c_{1}, \ldots, c_{N}\right) \equiv c_{0}+\sum_{i=1}^{N} u_{i}\left(c_{i}\right)
$$

where $c_{0}$ and $c_{i}$ are the consumption of numeraire good $O$ and non-numeraire good $i$, respectively. $\quad u_{i}\left(c_{i}\right)$ is assumed to be twice differentiable, increasing, and strictly concave.

Provided that income always exceeds expenditure on the nonnumeraire goods, the domestic demand for good $i$ can be expressed as a function of local price alone, i.e., $D_{i}\left(p_{i}\right)$.

Net import demand is then $M_{i}\left(p_{i}\right)=D_{i}\left(p_{i}\right)-Y_{i}\left(p_{i}\right)$. The world untaxed price, $p_{i w}$, is determined by the market-clearing condition:

$$
M_{i}\left(\tau_{i}, p_{i w}\right)+M_{i}^{*}\left(\tau_{i}^{*}, p_{i w}\right)=0 .
$$

From Equation (2), we can derive an expression for world equilibrium prices as a function of the 
policies in the two countries, i.e., $p_{i w}\left(\tau_{i}, \tau_{i}^{*}\right)$.

Domestic welfare is defined as the total amount of labor income, rent, tariff revenue, and consumer surplus. ${ }^{5}$

$$
W\left(\tau, \tau^{*}\right) \equiv L+\sum_{i=1}^{N} R_{i}\left(\tau_{i}, \tau_{i}^{*}\right)+\sum_{i=1}^{N} \tau_{i} M_{i}\left(\tau_{i}, \tau_{i}^{*}\right)+H\left[\sum_{i=1}^{H} u_{i}\left(c_{i}\left(\tau_{i}, \tau_{i}^{*}\right)\right)-\sum_{i=1}^{H} p_{i} c_{i}\left(\tau_{i}, \tau_{i}^{*}\right)\right] .
$$

The RP in each country sets its import tariff as a policy instrument in order to maximize its objective function. In the case in which the RP doesn't accept any donations, it is assumed to try to maximize its domestic welfare in order to enhance political support from the domestic electorate and ensure that it will stay in power after the next election. Therefore, the objective function of RP, $G^{N}$ ( $N$ to the upper right denotes "no donations"), is described as $G^{N}\left(\tau ; \tau^{*}\right) \equiv W\left(\tau, \tau^{*}\right) .6$

When each RP sets its tariff unilaterally to maximize its domestic welfare, taking the tariff of the other country as given, the first-order conditions for maximization of the RP's objective function is defined by

$$
G_{\tau_{i}}^{N} \equiv W_{\tau_{i}} \equiv M_{i} \phi_{i}+\tau_{i} \frac{\partial M_{i}}{\partial p_{i}}\left(1-\phi_{i}\right)=0
$$

where $-\phi_{i} \equiv \partial p_{i w} / \partial \tau_{i}, \quad 0<\phi_{i}<1 . \quad G_{\tau_{i}}^{N}$ and $W_{\tau_{i}}$ represent the partial derivative of the RP's objective function $\left(G^{N}\right)$ and domestic welfare $(W)$ with respect to the tariff on good $i\left(\tau_{i}\right)$, respectively. From Equations (2) and (4), the reaction function of $\tau_{i}$ can be expressed as

$$
\tau_{i}^{N}\left(\tau_{i}^{*}\right)=-\frac{p_{i} \phi_{i}}{\varepsilon_{i}^{M}\left(1-\phi_{i}\right)}=\frac{p_{i}^{*}}{\varepsilon_{i}^{M^{*}}}
$$

where $\varepsilon_{i}^{M} \equiv\left(\partial M_{i} / \partial p_{i}\right)\left(p_{i} / M_{i}\right)$ and $\varepsilon_{i}^{M^{*}} \equiv\left(\partial M_{i}^{*} / \partial p_{i}^{*}\right)\left(p_{i}^{*} / M_{i}^{*}\right)$ are the home and foreign price elasticities of import demand or export supply, depending on whether $M_{i}$ is positive or negative. Equation (5) is a familiar expression of optimal tariff, coming from the monopoly power to change the terms of trade. When the home country is the exporter of good $i$, for 
example, $\varepsilon_{i}^{M}>0$ and $\varepsilon_{i}^{M^{*}}<0$, then $\tau_{i}^{N}<0$, which means the home country levies positive tax on the export of good $i$. The changes of $\tau_{i}$ and $\tau_{i}^{*}$ under the condition of satisfying Equation (5) is denoted by $\left(d \tau_{i} / d \tau_{i}^{*}\right)_{R}$, and the case $\left(d \tau_{i} / d \tau_{i}^{*}\right)_{R}>0$ is considered hereinafter. Also, I assume a set of Equation (5) and the corresponding equation for the other country has a unique and stable equilibrium.

\section{Domestic Lobbying}

In this section, I examine the situation in which the RP accepts political contributions from domestic special interest groups (SIGs) only. The country has $K$ domestic SIGs which are formed by its people. The welfare of $j^{\text {th }}$ SIG is $W^{j}\left(\tau, \tau^{*}\right), j=1,2, \ldots, K$. Neither the preference of each SIG for tariffs nor the number of constituent members of it matters. There are two critical assumptions about SIGs which I accept hereinafter. First, SIGs are well organized in both countries, and all the individuals belong to just one of the domestic SIGs, that is, $W=\Sigma_{j} W^{j} \cdot{ }^{7}$ Second, $W^{j}$ is assumed to be twice differentiable, increasing, and strictly concave. These assumptions assure

$$
W_{\tau_{i}}=\sum_{j=1}^{K} W_{\tau_{i}}^{j}, W_{\tau_{i}^{*}}=\sum_{j=1}^{K} W_{\tau_{i}^{*}}^{j} .
$$

Each SIG decides its amount of donation to the national RP, which is in the position to set policy, in order to maximize SIG's welfare. The SIGs are assumed not to contribute to any opposition parties. The RP, on the other hand, chooses $\tau$ to maximize a weighted sum of donations from national SIGs and net aggregate national welfare after deducting donations, with $\tau^{*}$ as given. This decision-making process is analyzed as the following two-stage game. First, each SIG chooses its own bilateral contract schedule, which is publicly observable, simultaneously and noncooperatively. $j$-SIG in the home country offers a schedule of tariff vector, $\tau$, and the amount of donation, $C^{D j}$, to the RP ( $D$ to the upper right denotes "domestic donations"). The contract schedule can be rewritten as $C^{D j}\left(\tau, \tau^{*}(\tau)\right)=C^{D j}(\tau)$, since each SIG predicts correctly how the shift of our $\tau$ causes the other country to change $\tau^{*}$, based on the corresponding Equation (5) for the other country. Second, each RP decides whether to accept 
or reject the SIGs' offers, and then chooses $\tau$ (for the RP in the home country) or $\tau^{*}$ (in the foreign country), simultaneously and noncooperatively. RP's objective function under the circumstance of existing contribution from domestic SIGs, $G^{D}\left(\tau ; \tau^{*}\right)$, is

$$
G^{D}\left(\tau ; \tau^{*}\right) \equiv(1-\alpha)\left(W\left(\tau, \tau^{*}\right)-\sum_{j=1}^{K} C^{D j}(\tau)\right)+\alpha \sum_{j=1}^{K} C^{D j}(\tau)
$$

assuming $1 / 2<\alpha \leq 1$ in order that the RP values campaign contributions positively and, therefore, accepts them.

I solve this two-stage game backwards. At the second stage, the RP decides $\tau$ to maximize its objective function. Differentiation of Equation (7) with $\tau_{i}$ creates the following first-order condition for maximization of objective function for the RP.

$$
G_{\tau_{i}}^{D} \equiv(1-\alpha) W_{\tau_{i}}-(1-2 \alpha) \sum_{j=1}^{K} C_{\tau_{i}}^{D j}=0 .
$$

Next, at the first stage, SIGs choose contract offers. To calculate the equilibrium of contracts, I employ the idea of "truthful" equilibrium in Bernheim and Whinston (1986), which is applied to a model of endogenous policy determination by Grossman and Helpman (1994). Truthful equilibrium needs to be jointly efficient for SIGs and the RP. Joint efficiency means that $G^{D}$ is maximized, subject to constraints on the levels of each SIG's welfare anchor, $\bar{W}^{j}$. In equilibrium, the following equation is satisfied concerning the contract schedule of $j$ SIG. ${ }^{8}$

$$
C^{D j}(\tau)=W^{j}\left(\tau, \tau^{*}\right)-\bar{W}^{j}
$$

Each SIG decides the menu of monetary contribution to the national RP and the request of its tariff vector under the constraint of Equation (9). That is, in truthful equilibrium of contract offers, the following condition is satisfied for each SIG.

$$
C_{\tau_{i}}^{D j}=W_{\tau_{i}}^{j}+\left.W_{\tau_{i}^{*}}^{j} \frac{d \tau_{i}^{*}}{d \tau_{i}}\right|_{R^{*}}
$$

This equation means that, in the first stage, each SIG correctly predicts the reaction of the other country's tariff $\left(\left(d \tau_{i}^{*} / d \tau_{i}\right)_{R^{*}}\right)$ and takes it into consideration when it proposes its schedule of donation. ${ }^{9}$ Substitute Equation (10) into Equation (8) and use Equations (2) and (6), and the first-order condition for maximization of objective function for the RP is expressed 
as Equation (11).

$$
W_{\tau_{i}}+\left.\varphi W_{\tau_{i}^{*}} \frac{d \tau_{i}^{*}}{d \tau_{i}}\right|_{R^{*}}=0
$$

where $W_{\tau_{i}^{*}}=\left(M_{i}-\tau_{i} \partial M_{i} / \partial p_{i}\right) \phi_{i}^{*}$ and $\varphi=(2 \alpha-1) / \alpha$. Equation (11) defines reaction functions $\tau_{i}^{D}\left(\tau_{i}^{*}, \alpha\right)$ for the case when the RP accept political donations from national SIGs as follows:

$$
\tau_{i}^{D}\left(\tau_{i}^{*}, \alpha\right)=-\frac{p_{i}\left(\phi_{i}+\pi_{i}\right)}{\varepsilon_{i}^{M}\left(1-\phi_{i}-\pi_{i}\right)}=\frac{p_{i}^{*}\left(\phi_{i}+\pi_{i}\right)}{\varepsilon_{i}^{M^{*}}\left(\phi_{i}-\left(\phi_{i} \pi_{i} / 1-\phi_{i}\right)\right)},
$$

where $\pi_{i}=\varphi \phi_{i}^{*}\left(d \tau_{i}^{*} / d \tau_{i}\right)_{R^{*}}>0$, and $\pi_{i}<1-\phi_{i} \cdot{ }^{10}$

From the comparison of Equation (12) with (5), we see $0<\tau_{i}^{N}\left(\tau_{i}^{*}\right)<\tau_{i}^{D}\left(\tau_{i}^{*}, \alpha\right)$ when the country is an importer of good $i$ and levies a positive import tariff on it $\left(\varepsilon_{i}^{M}<0\right)$, while $\tau_{i}^{D}\left(\tau_{i}^{*}, \alpha\right)<\tau_{i}^{N}\left(\tau_{i}^{*}\right)<0$ when the country is an exporter of good $i$ and imposes a positive export tariff on it $\left(\varepsilon_{i}^{M}>0\right)$, at any $\tau_{i}^{*}$ and $\alpha$. This shows that the RP enhances trade barriers when it accepts political contributions from national SIGs. The rationale behind this relationship is that the welfare of the country increases when the other country decreases its trade barriers $\left(W_{\tau_{i}^{*}}<0\right.$ in the case that the country is the exporter of good $i$, and $W_{\tau_{i}^{*}}>0$ in the case that the country is its importer), and national SIGs can make the RP in the other country decrease its trade barriers by demanding that the domestic RP increase its trade barriers $\left(\left.\left(d \tau_{i}^{*} / d \tau_{i}\right)\right|_{R^{*}}>0\right)$ by means of political donations. We also see from Equation (12) the monotonous relationship between $\tau_{i}^{D}$ and $\alpha: \partial \tau_{i}^{D} / \partial \alpha>0$ when the country levies a positive import tariff on good $i\left(\varepsilon_{i}^{M}<0\right)$, while $\partial \tau_{i}^{D} / \partial \alpha<0$ when the country imposes a positive export tariff on it $\left(\varepsilon_{i}^{M}>0\right)$. This shows that when the RP highly values domestic 
donations, its trade barriers increases. These discussions are summarized in the following proposition.

Proposition 1. When an RP is permitted to accept political donations from national $S I G S$, an RP increases its import/export tariffs. The more an RP evaluates domestic donations, the more the country's tariffs increase.

From Equation (11), when $\alpha=1$ in the home country and $\alpha^{*} \leq 1 / 2$ in the foreign country (in the case in which a foreign RP doesn't receive domestic donations), the intersection point of reaction functions $\tau_{i}^{D}\left(\tau_{i}^{*}, \alpha\right)$ and $\tau_{i}^{D^{*}}\left(\tau_{i}, \alpha^{*}\right)$ satisfies the condition $\left.-\left(W_{\tau_{i}} / W_{\tau_{i}^{*}}\right)=\left(d \tau_{i}^{*} / d \tau_{i}\right)\right)_{R^{*}} . \quad$ This is a Stackleberg equilibrium in which the home country is the leader and foreign country is the follower. This implies that when the foreign country doesn't permit domestic lobbying activities, the home country is better off permitting domestic lobbying and moving equilibrium toward a Stackleberg equilibrium. Under the restriction of $1 / 2<\alpha \leq 1$ and $1 / 2<\alpha^{*} \leq 1$, however, a new equilibrium in the case of existing domestic lobbying in both countries can be the point at which both countries are worse off.

\section{Multilateral Lobbying}

This section considers the case of multilateral lobbying, in which each SIG is permitted to give its donation across the border, and each RP accepts donations both from domestic and foreign SIGs. $j$-SIG chooses publicly observable bilateral contract offers $C^{D j}(\tau)$ to the home $\mathrm{RP}$ (domestic lobbying) and $C^{C j}\left(\tau\left(\tau^{*}\right), \tau^{*}\right)=C^{C j}\left(\tau^{*}\right)$ to the foreign RP (cross-border lobbying). Similarly, $j^{*}$ SIG chooses $C^{D^{*} j^{*}}\left(\tau^{*}\right)$ to the foreign $\mathrm{RP}$ and $C^{C^{*} j^{*}}\left(\tau, \tau^{*}(\tau)\right)=C^{C^{*} j^{*}}(\tau)$ to the home RP. The RP's objective function for the home (foreign) country in the case of multilateral lobbying is $G^{M}\left(\tau ; \tau^{*}\right)\left(G^{M^{*}}\left(\tau^{*}, \tau\right)\right.$ ) (M to the upper right represents "multilateral lobbying"),

which is composed of national welfare $W\left(W^{*}\right)$, domestic donations $\Sigma_{j} C^{D j}\left(\Sigma_{j^{*}} C^{D^{*} j^{*}}\right)$, and cross-border donations $\sum_{j^{*}} C^{C^{*} j^{*}}\left(\Sigma_{j} C^{C j}\right)$. 
Policymakers' objective functions in the home country, $G^{M}\left(\tau ; \tau^{*}\right)$, and those in the foreign country, $G^{M^{*}}\left(\tau^{*} ; \tau\right)$, are, respectively,

$$
\begin{aligned}
& G^{M}\left(\tau ; \tau^{*}\right) \equiv(1-\alpha-\beta)\left(W\left(\tau, \tau^{*}\right)-\sum_{j=1}^{K} C^{D j}(\tau)-\sum_{j=1}^{K} C^{C j}\left(\tau^{*}\right)\right) \\
& +\alpha \sum_{j=1}^{K} C^{D j}(\tau)+\beta \sum_{j^{*}=1}^{K^{*}} C^{C^{*} j^{*}}(\tau) \\
& G^{M^{*}}\left(\tau^{*} ; \tau\right) \equiv\left(1-\alpha^{*}-\beta^{*}\right)\left(W^{*}\left(\tau, \tau^{*}\right)-\sum_{j^{*}=1}^{K^{*}} C^{D^{*} j^{*}}\left(\tau^{*}\right)-\sum_{j^{*}=1}^{K^{*}} C^{C^{*} j^{*}}(\tau)\right) \\
& +\alpha^{*} \sum_{j^{*}=1}^{K^{*}} C^{D^{*} j^{*}}\left(\tau^{*}\right)+\beta^{*} \sum_{j=1}^{K} C^{C j}\left(\tau^{*}\right)
\end{aligned}
$$

where $0<\beta<1,0<\beta^{*}<1, \alpha \leq 1-\beta \leq 2 \alpha$, and $\alpha^{*} \leq 1-\beta^{*} \leq 2 \alpha^{*}$. These restrictions assure that all the donations to the home $\mathrm{RP}\left(C^{D j}\right.$ and $\left.C^{C^{*} j^{*}}\right)$ and those to the foreign $\mathrm{RP}$ $\left(C^{D^{*} j^{*}}\right.$ and $\left.C^{C j}\right)$ have positive weights in $G^{M}\left(\tau ; \tau^{*}\right)$ and $G^{M^{*}}\left(\tau^{*} ; \tau\right)$. The RP of the home (foreign) country chooses $\tau_{i}\left(\tau_{i}^{*}\right)$ to maximize Equation (13a) (Equation (13b)), with $\tau_{i}^{*}\left(\tau_{i}\right)$ considered to be given.

I solve this problem backwards, in the same way as the domestic lobbying case. At the second stage, the home RP and the foreign RP decide $\tau_{i}$ and $\tau_{i}^{*}$, respectively, to maximize their objective functions. Differentiation of Equation (13a) with $\tau_{i}$ and that of Equation (13b) with $\tau_{i}^{*}$ create the first-order conditions for maximization of objective functions for the home RP as Equation (14a) and for the foreign RP as Equation (14b), respectively.

$$
G_{\tau_{i}}^{M} \equiv(1-\alpha-\beta) W_{\tau_{i}}-(1-2 \alpha-\beta) \sum_{j=1}^{K} C_{\tau_{i}}^{D j}+\beta \sum_{j^{*}=1}^{K^{*}} C_{\tau_{i}}^{C^{*} j^{*}}=0
$$




$$
G_{\tau_{i}^{*}}^{M^{*}} \equiv\left(1-\alpha^{*}-\beta^{*}\right) W_{\tau_{i}^{*}}^{*}-\left(1-2 \alpha^{*}-\beta^{*}\right) \sum_{j=1}^{K^{*}} C_{\tau_{i}^{*}}^{D^{*} j^{*}}+\beta^{*} \sum_{j=1}^{K} C_{\tau_{i}^{*}}^{C j}=0 .
$$

Next, at the first stage, each SIG chooses its schedule of donations. As in the previous section, I focus on truthful equilibrium, where all lobbies make a positive contribution. In other words, in equilibrium, the following equations are satisfied.

$$
\begin{aligned}
& C^{D j}(\tau)+C^{C j}\left(\tau^{*}\right)=W^{j}\left(\tau, \tau^{*}\right)-\bar{W}^{j}, \\
& C^{D^{*} j^{*}}\left(\tau^{*}\right)+C^{C^{*} j^{*}}(\tau)=W^{* j^{*}}\left(\tau, \tau^{*}\right)-\bar{W}^{* j^{*}} .
\end{aligned}
$$

These conditions are the same as the definition of weakly truthful transfers by Prat and Rustichini (2003). Each SIG decides its contribution schedules to both home and foreign RPs under the constraint of Equation (15a) or (15b). That is, in a truthful equilibrium of contract offers, the following conditions are satisfied for SIGs.

$$
\begin{aligned}
& C_{\tau_{i}}^{D j}+\left.C_{\tau_{i}^{*}}^{C j} \frac{d \tau_{i}^{*}}{d \tau_{i}}\right|_{R^{*}}=W_{\tau_{i}}^{j}+\left.W_{\tau_{i}^{*}}^{j} \frac{d \tau_{i}^{*}}{d \tau_{i}}\right|_{R^{*}},\left.\quad C_{\tau_{i}}^{D j} \frac{d \tau_{i}}{d \tau_{i}^{*}}\right|_{R}+C_{\tau_{i}^{*}}^{C j}=\left.W_{\tau_{i}}^{j} \frac{d \tau_{i}}{d \tau_{i}^{*}}\right|_{R}+W_{\tau_{i}^{*}}^{j}, \\
& C_{\tau_{i}^{*}}^{D^{*} j^{*}}+\left.C_{\tau_{i}}^{C^{*} j^{*}} \frac{d \tau_{i}}{d \tau_{i}^{*}}\right|_{R}=W_{\tau_{i}^{*}}^{* j^{*}}+\left.W_{\tau_{i}}^{* j^{*}} \frac{d \tau_{i}}{d \tau_{i}^{*}}\right|_{R},\left.\quad C_{\tau_{i}^{*}}^{D^{*} j^{*}} \frac{d \tau_{i}^{*}}{d \tau_{i}}\right|_{R^{*}}+C_{\tau_{i}}^{C^{*} j^{*}}=\left.W_{\tau_{i}^{*}}^{* j} \frac{d \tau_{i}^{*}}{d \tau_{i}}\right|_{R^{*}}+W_{\tau_{i}}^{* j^{*}} .
\end{aligned}
$$

Solving Equations (16a) and (16b) produces the following equations.

$$
C_{\tau_{i}}^{D j}=W_{\tau_{i}}^{j}, C_{\tau_{i}^{*}}^{C j}=W_{\tau_{i}^{*}}^{j}, \quad(17 \mathrm{~b}) \quad C_{\tau_{i}}^{D^{*} j^{*}}=W_{\tau_{i}}^{* j^{*}}, C_{\tau_{i}^{*}}^{C^{*} j^{*}}=W_{\tau_{i}^{*}}^{j^{*}}, .
$$

That is, when SIGs design their donation schedules to home and foreign RPs, all they need to take into consideration is the direct effect of home and foreign tariffs on their welfare. Strategic relationships between countries have no role to play in the case of multilateral lobbying, because such an indirect effect is properly replaced by a direct effect. In the absence of contributions from home SIGs to the foreign RP, any rise in the home export/import tariffs leads to a fall in the foreign import/export tariffs, which strategic effect home SIGs take into consideration when they decide their donations schedules. This indirect way to change the foreign tariff is, however, not efficient. By contributing to the foreign RP directly, this strategic effect is eliminated in equilibrium so that only the direct effect remains, which promotes efficiency of policy formation in the home country. This is the first benefit of cross-border political donations. The same arguments apply for the foreign country, and this result can be rewritten as the following proposition.

Proposition 2. When both domestic and cross-border lobbying activities are permitted, 
the schedules of donation presented by a SIG to a home RP and a foreign RP are determined by the direct effect of home tariffs and foreign tariffs, respectively, on the SIG's welfare.

Substitute Equations (17a) and (17b) into (14a) and (14b), then

(18a) $\quad W_{\tau_{i}}+\omega W_{\tau_{i}}^{*}=0$,

$$
W_{\tau_{i}^{*}}^{*}+\omega^{*} W_{\tau_{i}^{*}}=0,
$$

where $\omega=\beta / \alpha$ and $\omega^{*}=\beta^{*} / \alpha^{*}$. These equations show that, in the case of multilateral lobbying, the RP takes into account the impact of its trade policy on the welfare of the other country through cross-border donations, which makes the RP more cooperative with the other country. This is the second benefit of cross-border political donations. Equations (18a) and (18b) define reaction functions $\tau_{i}^{M}\left(\tau_{i}^{*}, \omega\right)$ for the home country and $\tau_{i}^{M^{*}}\left(\tau_{i}, \omega^{*}\right)$ for the foreign country, respectively, for the case in which the RP accepts political donations from both national SIGs and the other country's SIGs, which are written as follows:

$$
\begin{aligned}
& \tau_{i}^{M}\left(\tau_{i}^{*}, \omega\right)=(\omega-1) \frac{p_{i} \phi_{i}}{\varepsilon_{i}^{M}\left(1-\phi_{i}\right)}+\omega \tau_{i}^{*}=(1-\omega) \frac{p_{i}^{*}}{\varepsilon_{i}^{M^{*}}}+\omega \tau_{i}^{*}, \\
& \tau_{i}^{M^{*}}\left(\tau_{i}, \omega^{*}\right)=\left(\omega^{*}-1\right) \frac{p_{i}^{*} \phi_{i}^{*}}{\varepsilon_{i}^{M^{*}}\left(1-\phi_{i}^{*}\right)}+\omega^{*} \tau_{i}=\left(1-\omega^{*}\right) \frac{p_{i}}{\varepsilon_{i}^{M}}+\omega^{*} \tau_{i} .
\end{aligned}
$$

From the comparison of Equations (19a) with (5), we see $\tau_{i}^{M}\left(\tau_{i}^{*}, \omega\right)<\tau_{i}^{N}\left(\tau_{i}^{*}\right)$ when the home country is an importer of good $i\left(\varepsilon_{i}^{M}<0\right)$, while $\tau_{i}^{N}\left(\tau_{i}^{*}\right)<\tau_{i}^{M}\left(\tau_{i}^{*}, \omega\right)$ when the country is an exporter of it $\left(\varepsilon_{i}^{M}>0\right)$, at any $\tau_{i}^{*}$ and $\omega$. This shows that the RP reduces trade barriers in the case of multilateral lobbying, due to the two benefits of cross-border lobbying mentioned above. We also see again from Equation (19a) the monotonous relationship between $\tau_{i}^{M}$ and $\beta: \partial \tau_{i}^{M} / \partial \beta<0$ when the country imports $\operatorname{good} i$, while $\partial \tau_{i}^{M} / \partial \beta>0$ when the country exports it. This shows that when the RP highly values cross-border donations, its trade barriers decreases. In the case of multilateral lobbying, the strategic relationships between tariffs in two countries disappear, and the RP only counts the direct effect of its trade policy on the welfare of both countries. The reduction of trade barriers (export and import tariffs) in a country is beneficial for the other country, and the more highly the RP values political 
donations from abroad, the more the RP lowers its trade barriers for the foreign country. From Equations (19a) and (19b) I derived the third proposition.

Proposition 3. When an RP accepts both domestic and cross-border donations, that $\mathrm{RP}$ decreases its import/export tariffs. The more highly an RP values cross-border donations compared with domestic donations, the more the country's tariffs decrease.

Comparing this condition with the case of no donations as in Section 2, the shift of tariff reaction curves after admitting only domestic lobbying is in the opposite direction from the shift of those after admitting multilateral lobbying. This results from the differences between the SIG's and RP's behavior in two cases. Consider the relationship between the donations schedules of SIGs and other country's tariffs first. In both cases, the home country's welfare increases when the foreign country lessens its export/import tariffs. In order to have the foreign RP decrease its trade barriers, in the case of domestic donations, home SIGs request the home RP to increase its own export/import tariffs by means of domestic donations, which leads the shift of reaction curves of home tariffs to the direction of enhancing trade barriers. This is an indirect way of decreasing the other country's trade taxes, by employing the strategic relationships between trade policies. In the case of multilateral lobbying, however, home SIGs can use a direct way; they directly request the foreign RP to decrease its trade barriers by means of cross-border donations. The reaction curves of home tariffs, therefore, don't change. Second, as for RPs' objective functions, RPs don't consider the welfare of the other country in the case of domestic lobbying, and so the reaction curves of home tariffs don't depend on it. In the case of multilateral lobbying, however, the home RP needs to take care of the other country's welfare, because it receives cross-border donations from foreign SIGs. The reaction curves of home tariffs, therefore, shift to the direction of lowering trade barriers. ${ }^{11}$

\section{Efficient Policies}

Multilateral lobbying moves the trade policy of two countries toward a Pareto-efficient

pair of tariffs. It doesn't guarantee, however, that a new equilibrium locates on Pareto-efficiency locus. In this section, I examine closely the condition for multilateral lobbying to yield Pareto efficiency and to maximize the weighted sum of two countries' welfare.

A Pareto-efficiency locus is defined as the set of a pair of tariff vectors which satisfies the following condition.

$$
\left.\frac{d \tau_{i}}{d \tau_{i}^{*}}\right|_{d W=0}=\left.\frac{d \tau_{i}}{d \tau_{i}^{*}}\right|_{d W^{*}=0} .
$$


$\left(\tau^{P E}, \tau^{* P E}\right)$ are the tariff vectors which satisfy Equation (20), and are called "efficient tariffs."

The pair of efficient tariffs is achieved under the condition $\omega \omega^{*}=1$, which is verified as follows: $d W=0$ and $d W^{*}=0$ require the conditions, respectively,

(21a) $-\frac{W_{\tau_{i}^{*}}}{W_{\tau_{i}}}=\frac{d \tau_{i}}{d \tau_{i}^{*}}, \quad(21 \mathrm{~b}) \quad-\frac{W_{\tau_{i}^{*}}^{*}}{W_{\tau_{i}}^{*}}=\frac{d \tau_{i}}{d \tau_{i}^{*}}$.

Under the equilibrium of multilateral lobbying, both Equations (18a) and (18b) are satisfied, so if we substitute Equation (18b) into Equation (21a) and Equation (18a) into Equation (21b), we find that Equation (20) is satisfied for all goods when $\omega \omega^{*}=1$. Next, substitute $\omega \omega^{*}=1$ into Equation (18b), and we obtain $W_{\tau_{i}^{*}}+\omega W_{\tau_{i}^{*}}^{*}=0$. This equation and Equation (18a) are considered to be the first-order conditions for maximization of the weighted sum of home and foreign welfare, where $\omega$ is a weight for foreign welfare. From these arguments, I obtain the next proposition.

Proposition 4. $\left(\tau^{P E}, \tau^{* P E}\right)$ attains equilibrium in the case of multilateral lobbying when $\omega \omega^{*}=1 . \quad\left(\tau^{P E}, \tau^{* P E}\right)$ maximizes the weighted sum of home and foreign welfare, where $\omega$ is a weight for foreign welfare.

It is directly derived from Proposition 4 that the condition which maximizes the unweighted sum of home and foreign welfare, i.e., world welfare, is $\left(\omega, \omega^{*}\right)=(1,1)$. This means that when each RP evaluates domestic and cross-border donations with the same weight ( $\alpha=\beta$ and $\alpha^{*}=\beta^{*}$ ) potential benefit from multilateral lobbying is maximized. The following is a straightforward corollary of Proposition 4.

Corollary. World welfare is maximized when each RP makes no distinction between domestic and cross-border donations.

Solving Equations (19a) and (19b) with the condition $\left(\omega, \omega^{*}\right)=(1,1)$ yields the result $\tau_{i}-\tau_{i}^{*}=0$. This condition implies that two countries set the net trade barriers of good $i$ at zero so as not to distort trade flows, and then the local prices of good $i$ are equal to each other. $\tau_{i}-\tau_{i}^{*}=0$ does not guarantee, however, that both countries increase their welfare by 
multilateral lobbying, even when $\tau_{i}=\tau_{i}^{*}=0$. In order to assure that both countries are better off, we need the introduction of a system of international income redistribution. One implication of this theoretical fact is that, in order to extract the full potential benefit from multilateral lobbying, it is necessary not only to have each RP evaluate domestic and cross-border donations with the same weight but also to establish some sort of international institution which handles negotiations about international income transfer and its effective execution. It may require arduous negotiation to reach an agreement among nations to establish such an institution and to launch an effective and powerful scheme of international income transfer, beneficial for all participants. The institution is, however, essential in distributing the benefit of international policy coordination brought about through multilateral lobbying to all nations. ${ }^{12}$

\section{Extension: International Trade with Negative Externality}

The model developed in the text doesn't deal with the external effect. Externality does not, however, change the propositions mentioned above if welfare functions preserve concavity. This section illustrates this statement by introducing externality negative to welfare into the model, along the lines of Ederington (2001), Conconi (2003), and Limão (2005). They studied trade and domestic policies in large open countries with the presence of negative externalities arising from their production. In this section I examine the determination of policies with the existence of negative externality, first in the context that there are only trade policies, and second in the context that there are both trade and domestic policies.

\subsection{The case of one policy tool: tariff}

I slightly modify the model setting presented in Section 2; the productions of non-numeraire goods are assumed to be accompanied by international negative externalities as by-products in both countries. This decreases the welfare of individuals in both countries in a nonpecuniary manner. I examine hereinafter the determination of $\left(\tau_{i}, \tau_{i}^{*}\right)$ in the cases of no-lobbying and of cross-lobbying.

The utility function of individuals (Equation (1)) is modified to the following form:

$$
u\left(c_{0}, c_{1}, \ldots, c_{N}, Z\right) \equiv c_{0}+\sum_{i=1}^{N} u_{i}\left(c_{i}\right)-Z
$$


where $Z$ is total externalities to the country from the productions of non-numeraire goods. The degree of $Z$ is a function of the outputs in both home and foreign countries as follows:

$$
Z\left(\tau, \tau^{*}\right) \equiv \sum_{i=1}^{N}\left[\eta_{i d} Y_{i}\left(p_{i}\left(\tau_{i}, \tau_{i}^{*}\right)\right)+\eta_{i c} Y_{i}^{*}\left(p_{i}^{*}\left(\tau_{i}, \tau_{i}^{*}\right)\right)\right]
$$

where $\eta_{i d} \geq 0$ is the parameter of externality which represents the extent to which domestic production of good $i$ decreases the utility of individuals. $\eta_{i c} \geq 0$ is the parameter of cross-border externality from the production of good $i$ in the other country. Equation (23) is the same as Conconi (2003). If $\eta_{i c}=\eta_{i c}^{*}=0$, then there is no cross-border externality concerning the production of good $i$, which case Ederington (2001) considered. If $\eta_{i c}=\eta_{\text {id }} \neq 0$ and $\eta_{i c}^{*}=\eta_{i d}^{*} \neq 0$, then the externalities from two countries are completely indifferent for the home and the foreign, respectively. ${ }^{13}$

Domestic welfare is redefined as the total amount of labor income, rent, tariff revenue, consumer surplus, plus the negative effect of externalities.

$$
\begin{gathered}
W\left(\tau, \tau^{*}\right) \equiv L+\sum_{i=1}^{N} R_{i}\left(\tau_{i}, \tau_{i}^{*}\right)+\sum_{i=1}^{N} \tau_{i} M_{i}\left(\tau_{i}, \tau_{i}^{*}\right)+H\left[\sum_{i=1}^{H} u_{i}\left(c_{i}\left(\tau_{i}, \tau_{i}^{*}\right)\right)-\sum_{i=1}^{H} p_{i} c_{i}\left(\tau_{i}, \tau_{i}^{*}\right)\right] \\
-H Z\left(\tau, \tau^{*}\right) .
\end{gathered}
$$

When the RP sets its tariff unilaterally to maximize its domestic welfare, taking the tariff of the other country as given, the resulting reaction function of tariff on good $i$ is defined by

$$
\tau_{i}=\frac{p_{i}^{*}}{\varepsilon_{i}^{M^{*}}}+\frac{H \eta_{i d} \varepsilon_{i}^{Y}}{m_{i} \varepsilon_{i}^{M}}-\frac{H \eta_{i c} \varepsilon_{i}^{Y^{*}}}{m_{i}^{*} \varepsilon_{i}^{M^{*}}}
$$

where $\quad \varepsilon_{i}^{Y} \equiv\left(\partial Y_{i} / \partial p_{i}\right)\left(p_{i} / Y_{i}\right)>0 \quad, \quad \varepsilon_{i}^{Y^{*}} \equiv\left(\partial Y_{i}^{*} / \partial p_{i}^{*}\right)\left(p_{i}^{*} / Y_{i}^{*}\right)>0 \quad, \quad m_{i} \equiv M_{i} / Y_{i} \quad, \quad$ and $m_{i}^{*} \equiv M_{i}^{*} / Y_{i}^{*}$. Compared with Equation (5), Equation (25) has two additional terms: $H \eta_{i d} \varepsilon_{i}^{Y} / m_{i} \varepsilon_{i}^{M}$ and $H \eta_{i c} \varepsilon_{i}^{Y^{*}} / m_{i}^{*} \varepsilon_{i}^{M^{*}} . H \eta_{i d} \varepsilon_{i}^{Y} / m_{i} \varepsilon_{i}^{M}$ represents the welfare effect of 
externalities from the local production of good $i$, which varies according to the local price of good i. $H \eta_{i d} \varepsilon_{i}^{Y} / m_{i} \varepsilon_{i}^{M}<0$ always holds, which means that the increase of $\tau_{i}$ strengthens the negative externality on local welfare through the increase of the local price of good $i$ and, therefore, the production of it. ${ }^{14} H \eta_{i c} \varepsilon_{i}^{Y^{*}} / m_{i}^{*} \varepsilon_{i}^{M^{*}}$ represents, on the other hand, the welfare effect of externalities from the foreign production of $\operatorname{good} i . \quad-H \eta_{i c} \varepsilon_{i}^{Y^{*}} / m_{i}^{*} \varepsilon_{i}^{M^{*}}>0$ always holds, which means that the increase of $\tau_{i}$ lessens the negative externality, through the decrease of the foreign price of good $i$, which decreases in turn the foreign production of good $i$. The reaction function of $\tau_{i}$, determined from Equation (25), might be higher or lower than that from Equation (5), depending on the relative strengths of these two terms.

In the case of multilateral lobbying with $\left(\omega, \omega^{*}\right)=(1,1)$, the reaction functions of tariffs on good $i$ in the home and foreign countries are expressed as ${ }^{15}$

$$
\tau_{i}=\frac{\left(H \eta_{i d}+H^{*} \eta_{i c}^{*}\right) \varepsilon_{i}^{Y}}{m_{i} \varepsilon_{i}^{M}}<0
$$

Equation (26) shows that the level of $\tau_{i}$ is determined by the effect of $\tau_{i}$ on negative externality caused from the domestic production of good $i$ to the welfare of the home country, $H \eta_{i d} \varepsilon_{i}^{Y} / m_{i} \varepsilon_{i}^{M}$, and by the effect on externality to the welfare of the foreign country, $H^{*} \eta_{i c} \varepsilon_{i}^{Y} / m_{i} \varepsilon_{i}^{M}$. This form represents the fact that optimal assignment for trade policy in a country, with the existence of negative externality, exists to redress its own externality. Equation (26) doesn't include the term of optimal tariff. The monopoly power of countries is eliminated completely in order to maximize world welfare.

\subsection{The case of two policy tools: tariff and production tax}

The previous part considers tariffs of two countries as a single policy tool. The theoretical framework of this paper can apply, however, to the more general situation where each country has more than one policy tool. I consider in this part the case where each country 
has two policy tools: tariff (trade policy) and production tax (domestic policy).

The theoretical framework in the case of two policy tools is similar to that in the previous part. One critical difference is that there is a wedge between consumer and producer prices because of the introduction of a vector of specific production taxes $t=\left(t_{1}, \ldots, t_{N}\right)$. The producer price of good $i$ is thus equal to $p_{i s}=p_{i w}+\tau_{i}-t_{i}$, while the consumer price is $p_{i c}=p_{i w}+\tau_{i}$. The output of good $i$ is redefined as $Y_{i}\left(p_{i s}\right)=\partial R_{i} / \partial p_{i s}$, the total externalities to the country $Z$ is expressed as $Z\left(\tau, t, \tau^{*}, t^{*}\right) \equiv \sum_{i=1}^{N}\left[\eta_{i d} Y_{i}\left(p_{i s}\left(\tau_{i}, t_{i}, \tau_{i}^{*}, t_{i}^{*}\right)\right)\right.$ $\left.+\eta_{i c} Y_{i}^{*}\left(p_{i s}^{*}\left(\tau_{i}, t_{i}, \tau_{i}^{*}, t_{i}^{*}\right)\right)\right]$, net import demand is $M_{i}\left(p_{i c}, p_{i s}\right)=D_{i}\left(p_{i c}\right)-Y_{i}\left(p_{i s}\right)$, and the world equilibrium price which satisfies the market-clearing condition is given by $p_{i w}\left(\tau_{i}, t_{i}, \tau_{i}^{*}, t_{i}^{*}\right)$.

Domestic welfare is then rewritten in the same form as Conconi (2003).

$$
\begin{gathered}
W\left(\tau, t, \tau^{*}, t^{*}\right) \equiv L+\sum_{i=1}^{N} R_{i}\left(\tau_{i}, t_{i}, \tau_{i}^{*}, t_{i}^{*}\right)+\sum_{i=1}^{N} \tau_{i} M_{i}\left(\tau_{i}, t_{i}, \tau_{i}^{*}, t_{i}^{*}\right)+\sum_{i=1}^{N} t_{i} Y_{i}\left(\tau_{i}, t_{i}, \tau_{i}^{*}, t_{i}^{*}\right) \\
+H\left[\sum_{i=1}^{H} u_{i}\left(c_{i}\left(\tau_{i}, t_{i}, \tau_{i}^{*}, t_{i}^{*}\right)\right)-\sum_{i=1}^{H} p_{i c} c_{i}\left(\tau_{i}, t_{i}, \tau_{i}^{*}, t_{i}^{*}\right)\right]-H Z\left(\tau, t, \tau^{*}, t^{*}\right) .
\end{gathered}
$$

Objective functions of RPs and donation schedules of SIGs are extended so as to incorporate $t$ and $t^{*}$ in the same manner as $\tau$ and $\tau^{*}{ }^{16}$

When the RP sets its tariff and production tax unilaterally to maximize its domestic welfare, taking the tariff of the other country as given, the resulting reaction functions of tariff and production tax on good $i$ are defined by, respectively, $\tau_{i}=\left(p_{i}^{*} / \varepsilon_{i}^{M^{*}}\right)-\left(H \eta_{i c} \varepsilon_{i}^{Y^{*}} / m_{i}^{*} \varepsilon_{i}^{M^{*}}\right)$ and $t_{i}=H \eta_{i d}$. In this case, $\tau_{i}$ is determined from the terms of trade effect: $p_{i}^{*} / \varepsilon_{i}^{M^{*}}$ is the direct welfare effect of the change of the terms of trade by $\tau_{i}$, while $-H \eta_{i c} \varepsilon_{i}^{Y^{*}} / m_{i}^{*} \varepsilon_{i}^{M^{*}}$ is the indirect welfare effect through the change of negative externality from the production of the other country, which is caused by the change of the terms of trade. $t_{i}$ is, on the other hand, 
set from the level of negative externality from the home production: $t_{i}=H \eta_{i d}$ is a nondistortionary production tax to counter the local direct externality. Note that $t_{i}$ is independent of $\tau_{i}, \tau_{i}^{*}$, and $t_{i}^{*}$, while $\tau_{i}$ and $\tau_{i}^{*}$ are interdependent.

In the case of multilateral lobbying, the schedule of donations from j-SIG in the home country is slightly rewritten from Equation (15a) to $C^{D j}(\tau, t)+C^{C j}\left(\tau^{*}, t^{*}\right)=$ $W^{j}\left(\tau, t, \tau^{*}, t^{*}\right)-\bar{W}^{j}$. In a truthful equilibrium of contract offers, the conditions $C_{t_{i}}^{D j}=W_{t_{i}}^{j}$ and $C_{t_{i}^{*}}^{C j}=W_{t_{i}^{*}}^{j}$ are satisfied, in addition to Equation (17a), for $j^{-S I G . ~ W h e n ~}\left(\omega, \omega^{*}\right)=(1,1)$, the equilibrium tariffs and production taxes are derived as $\tau_{i}-\tau_{i}^{*}=0$ and $\left(\varepsilon_{i}^{Y}\left(t_{i}-H \eta_{i d}-H^{*} \eta_{i c}^{*}\right) / m_{i}\right)-\left(\varepsilon_{i}^{Y^{*}}\left(t_{i}^{*}-H \eta_{i c}-H^{*} \eta_{i d}^{*}\right) / m_{i}^{*}\right)=0$, respectively. $\quad$ The former condition is the same as that in Section 6, while the latter condition requires total production tax revenue of the world to be equal to total welfare loss of the world from negative externalities of productions.

\section{Concluding Remarks}

This paper examines the effects of lobbying activities across borders on determining trade policies in a multi-principal, multi-agent, and menu-auction model. The main result is that multilateral lobbying, i.e., the situation in which both domestic and cross-border lobbying activities are permitted, brings the equilibrium of tariffs in countries towards the Pareto-efficiency locus, on the assumption that all the individuals belong to one of the domestic SIGs. When each RP evaluates political contributions from national SIGs and from abroad with the same weight, a Pareto-efficiency is attained at which the unweighted sum of the two countries' welfare is maximized. In other words, in order to maximize world welfare, each government should allow every party the right to raise political funds from abroad, and each party should treat all the contributions equally, regardless of the nation of origin.

This result reestablishes the theoretical findings of Becker (1983) and Grossman and Helpman (1994) about the relationship of lobbying and efficient policies. Becker (1983) presented the proposition that competition among pressure groups favors efficient methods of 
domestic taxation in a country, and Grossman and Helpman (1994) stated that in a small economy free trade prevails when all voters belong to one of the interest groups. My analysis extends these statements, and proposes that efficient policies are successfully adopted even in the case of large countries, if RPs treat domestic and cross-border donations equally. This would not assure, however, that the new equilibrium of the Pareto-efficient tariffs is beneficial for all countries. To convert efficiently the potential benefit of multilateral lobbying into an actual benefit for each country, an effective and powerful international scheme for income transfer is essential.

Readers may doubt some of the assumptions in the model, especially those about principals (SIGs), agents (RPs), and an outcome (truthful equilibrium) of a menu-auction. First, as for SIGs, an extreme assumption is that every individual can express his or her preference to both home and foreign RPs through the SIG to which it belongs. Reflecting on the behavior of actual SIGs, it is natural to consider the existence of some political costs of forming and maintaining SIGs, which result in some individuals choosing not to participate in lobbying activities. Mitra (1999) introduces this political cost and analyzes endogenous lobby formation. My assumption corresponds to Mitra's model when every individual participates in a SIG and costs of lobbying are sufficiently low. I have to admit, however, that collecting information on the tax policies of all countries and making out their schedules of donation could be laborious work for all SIGs. Second, as for RPs, the total amount of donations each RP collects becomes excessively large when all SIGs follow truthful transfers, since each RP has a monopolistic power in the legislative branch of government. This kind of fund-collecting behavior by political parties is unacceptable to citizens. And third, the practicability of truthful transfers might be suspect. Kirchsteiger and Prat (2001) run an experiment and find that the truthful alternative is chosen in only a fraction of all matches. This undermines our discussion, since truthful equilibrium is a crucial characteristic of all the propositions presented in the text.

Despite these caveats, the main message of this analysis still holds. That is, foreign political contributions per se are not harmful in the world. Rather, they help every government to be aware of foreign concern for its economic policy, and to become more sensitive to the impact of its policy on world welfare. Binding contracts of cross-border political contributions with overseas RPs are efficient tools by which SIGs can reveal their interests in the economic policies of foreign countries. In this sense, free international lobbying serves well as a catalyst for creating a more cooperative and efficient world economy. Some may think that cross-border donations become threats against nations, sovereignty and their right to political self-determination. With the rise of multinational corporations and the increase in foreign trade and investment, foreign people seek to influence the domestic policies of the 
nations in which they do business. This growing foreign political influence has caused elected officials of many countries to fear that their nations' political and economic independence is at risk. Seen from a different point of view, these domestic concerns are an indication that governments need to take into account the impact of their legislation on the welfare of other countries. Based on the model in this paper, such awareness can be considered an important component in future meaningful international cooperation. 
Table 1: Number of countries which ban foreign donations:

by income and region

Is there a full ban on foreign donations to political parties?

Yes No

Total:

$40 \quad 71$

GDP (million US\$, 2003):

$\begin{array}{lll}100,000 \text { plus } & 14 & 15 \\ 10,000-99,999 & 13 & 13 \\ 1,000-9,999 & 11 & 25 \\ \text { up to } 999 & 2 & 18\end{array}$

Per capita GDP (US\$, 2003):

$\begin{array}{lll}10,000 \text { plus } & 11 & 17 \\ 3,000-9,999 & 10 & 19 \\ 1,000-2,999 & 10 & 15 \\ \text { up to } 999 & 9 & 20\end{array}$

Region: 
Africa

The Americas

Asia

Europe

Oceania
$4 \quad 19$

$12 \quad 20$

64

$17 \quad 17$

111

Source: Austin and Tjernström (2003), World Bank (2004)

\section{References}

Austin, Reginald and Maja Tjernström (eds.) (2003), Funding of Political Parties and Election Campaigns, Stockholm: International Institute for Democracy and Electoral Assistance.

Bagwell, Kyle and Robert W. Staiger (1990), A Theory of Managed Trade, American

Economic Review, Vol. 80, No. 4, 779-795.

Bagwell, Kyle and Robert W. Staiger (1999), An Economic Theory of GATT, American Economic Review, Vol. 89, No. 1, 215-248.

Becker, Gary S. (1983), A Theory of Competition Among Pressure Groups for Political Influence, Quarterly Journal of Economics, Vol. 98, No. 3, 371-400. 
Bernheim, B. Douglas and Michael D. Whinston (1986), Menu Auction, Resource Allocation, and Economic Influence, Quarterly Journal of Economics, Vol. 101, No. 1, 1-32.

Blanchard, Emily J. (2005), Foreign Direct Investment, Endogenous Tariffs, and Preferential Trade Agreements, mimeo.

Committee on Standards in Public Life, the U.K. (1998), Fifth Report of the Committee on Standards in Public Life: The Funding of Political Parties in the United Kingdom, London: Stationery Office.

Conconi, Paola. (2003), Green Lobbies and Transboundary Pollution in Large Open Economies, Journal of International Economics, Vol. 59, No. 2, 399-422.

Damrosch, Lori F. (1989), Politics across Borders: Nonintervention and Nonforcible Influence over Domestic Affairs, American Journal of International Law, Vol. 83, No. 1, 1-50.

Devereux, Michael B. and Khang Min Lee (1999), Endogenous Trade Policy and the Gains from International Financial Markets, Journal of Monetary Economics, Vol. 43, No. $1,35-59$

Dixit, Avinash K. (1987), Strategic Aspects of Trade Policy, in Truman F. Bewley (ed.), Advances in Economic Theory: Fifth World Congress, Cambridge: Cambridge University Press, 329-362.

Ederington, Josh (2001), International Coordination of Trade and Domestic Policies, American Economic Review, Vol. 91, No. 5, 1580-1593.

Gawande, Kishore, Pravin Krishna, and Michael J. Robbins (2004), Foreign Lobbies and US Trade Policy, NBER Working Paper 10205.

Grossman, Gene M. and Elhanan Helpman (1994), Protection for Sale, American Economic Review, Vol. 84, No. 4, 833-850.

Grossman, Gene M. and Elhanan Helpman (1995), The Politics of Free-Trade Agreements, American Economic Review, Vol. 85, No. 4, 667-690.

Grossman, Gene M. and Elhanan Helpman (1996), Electoral Competition and Special Interest Politics, Review of Economic Studies, Vol. 63, No. 2, 265-286.

Hamada, Koichi (1993), International Negotiations and Domestic Conflicts: A Case for Counterlobbying, in Lawrence R. Klein (ed.), A Quest for a More Stable World Economic System: Restructuring at a Time of Cyclical Adjustment, Boston: Kluwer Academic Publishers.

Kee, Hiau Looi, Marcelo Olarreaga, and Peri Silva (2004), Market Access for Sale: Latin America's Lobbying for U.S. Tariff Preferences, The World Bank Policy Research Working Paper Series 3198. 
Kirchsteiger, Georg and Andrea Prat (2001), Inefficient Equilibria in Lobbying, Journal of Public Economics, Vol. 82, No. 3, 349-375.

Krishna, Pravin and Devashish Mitra (2005), Reciprocated Unilateralism in Trade Policy, Journal of International Economics, Vol. 65, No. 2, 461-487.

Limão, Nuno (2005), Trade Policy, Cross-Border Externalities and Lobbies: Do Linked

Agreements Enforce More Cooperative Outcomes?, Journal of International Economics, forthcoming.

Maggi, Giovanni (1999), The Role of Multilateral Institutions in International Trade Cooperation, American Economic Review, Vol. 89, No. 1, 190-214.

Mitra, Devashish (1999), Endogenous Lobby Formation and Endogenous Protection:

A Long-Run Model of Trade Policy Determination, American Economic Review, Vol. 89, No. 5, 1116-1134.

Powell, Jeffrey K. (1996), Prohibitions on Campaign Contributions from Foreign Sources: Questioning Their Justification in a Global Interdependent Economy, University of Pennsylvania Journal of International Economic Law, Vol. 17, No. 3, 957-993.

Prat, Andrea and Aldo Rustichini (2003), Games Played Through Agents, Econometrica, Vol. 71, No. 4, 989-1026.

Riezman, Raymond (1991), Dynamic Tariffs with Asymmetric Information, Journal of International Economics, Vol. 30, No. 3-4, 267-283.

World Bank (2004), World Development Indicators 2004, Washington, D.C.: The World Bank.

\section{Appendix: First-Order Conditions in Section 6.2.}

First-order conditions for maximizing Equation (27) with respect to $\tau_{i}, t_{i}, \tau_{i}^{*}$, and

$t_{i}^{*}$ are, respectively,

(A.1) $\quad W_{\tau_{i}} \equiv M_{i} \phi_{i}+\tau_{i}\left(\frac{\partial D_{i}}{\partial p_{i c}}-\frac{\partial Y_{i}}{\partial p_{i s}}\right)\left(1-\phi_{i}\right)+t_{i} \frac{\partial Y_{i}}{\partial p_{i s}}\left(1-\phi_{i}\right)$ 


$$
-H\left[\eta_{d} \frac{\partial Y_{i}}{\partial p_{i s}}\left(1-\phi_{i}\right)-\eta_{c} \frac{\partial Y_{i}^{*}}{\partial p_{i s}^{*}} \phi_{i}\right]=0
$$

(A.2) $\quad W_{t_{i}} \equiv-M_{i} \delta_{i}+\tau_{i}\left(\frac{\partial D_{i}}{\partial p_{i c}} \delta_{i}-\frac{\partial Y_{i}}{\partial p_{i s}}\left(\delta_{i}-1\right)\right)+t_{i} \frac{\partial Y_{i}}{\partial p_{i s}}\left(\delta_{i}-1\right)$

$$
+H\left[\eta_{d} \frac{\partial Y_{i}}{\partial p_{i s}}\left(1-\delta_{i}\right)-\eta_{c} \frac{\partial Y_{i}^{*}}{\partial p_{i s}^{*}} \delta_{i}\right]=0
$$

$$
W_{\tau_{i}^{*}} \equiv M_{i} \phi_{i}^{*}-\tau_{i}\left(\frac{\partial D_{i}}{\partial p_{i c}}-\frac{\partial Y_{i}}{\partial p_{i s}}\right) \phi_{i}^{*}-t_{i} \frac{\partial Y_{i}}{\partial p_{i s}} \phi_{i}^{*}+H\left[\eta_{d} \frac{\partial Y_{i}}{\partial p_{i s}} \phi_{i}^{*}-\eta_{c} \frac{\partial Y_{i}^{*}}{\partial p_{i s}^{*}}\left(1-\phi_{i}\right)\right]=0,
$$

$$
W_{t_{i}^{*}} \equiv-M_{i} \delta_{i}^{*}+\tau_{i}\left(\frac{\partial D_{i}}{\partial p_{i c}}-\frac{\partial Y_{i}}{\partial p_{i s}}\right) \delta_{i}^{*}+t_{i} \frac{\partial Y_{i}}{\partial p_{i s}} \delta_{i}^{*}-H\left[\eta_{d} \frac{\partial Y_{i}}{\partial p_{i s}} \delta_{i}^{*}-\eta_{c} \frac{\partial Y_{i}^{*}}{\partial p_{i s}^{*}}\left(1-\delta_{i}^{*}\right)\right]=0,
$$

where $\delta_{i}=\partial p_{i w} / \partial t_{i}, \delta_{i}^{*}=\partial p_{i w} / \partial t_{i}^{*}, 0<\delta_{i}<1$, and $0<\delta_{i}^{*}<1$. Reaction functions of tariff and production tax on good $i, \tau_{i}=\left(p_{i}^{*} / \varepsilon_{i}^{M^{*}}\right)-\left(H \eta_{i c} \varepsilon_{i}^{Y^{*}} / m_{i}^{*} \varepsilon_{i}^{M^{*}}\right)$ and $t_{i}=H \eta_{i d}$, are acquired from Equations (A.1), (A.2), and the market-clearing condition, assuming $\phi_{i} \neq \delta_{i}$.

When $\left(\omega, \omega^{*}\right)=(1,1)$, the equilibrium tariffs and production taxes which maximize world welfare satisfy the following conditions.

(A.5) $\quad W_{\tau_{i}}+W_{\tau_{i}}^{*}=0$,

(A.6) $\quad W_{t_{i}}+W_{t_{i}}^{*}=0$,

(A.7) $\quad W_{\tau_{i}^{*}}+W_{\tau_{i}^{*}}^{*}=0$,

(A.8) $\quad W_{t_{i}^{*}}+W_{t_{i}^{*}}^{*}=0$.

One way of calculating the equilibrium tariffs and production taxes is as follows: from Equations (A.5) and (A.7), $W_{\tau_{i}}+W_{\tau_{i}}^{*}+W_{\tau_{i}^{*}}+W_{\tau_{i}^{*}}^{*}=0$, assuming $\phi_{i}+\phi_{i}^{*} \neq 1$. Also, from 
Equations (A.6) and (A.8), $W_{t_{i}}+W_{t_{i}}^{*}+W_{t_{i}^{*}}+W_{t_{i}^{*}}^{*}=0$, assuming $\delta_{i}+\delta_{i}^{*} \neq 1$. From these two equations, we acquire $\quad \tau_{i}-\tau_{i}^{*}=0$ and $\left(\varepsilon_{i}^{Y}\left(t_{i}-H \eta_{i d}-H^{*} \eta_{i c}^{*}\right) / m_{i}\right)$ $-\left(\varepsilon_{i}^{Y^{*}}\left(t_{i}^{*}-H \eta_{i c}-H^{*} \eta_{i d}^{*}\right) / m_{i}^{*}\right)=0$

1 The positive and negative opinions for political donation from abroad in the context of the U.K. are well summarized in the report of the Committee on Standards in Public Life (Committee on Standards in Public Life, the U.K., 1998), presented to the Parliament in 1998 as background material to discuss the regulations of political funding. In this document, the arguments against the imposition of a ban on foreign donations are categorized into six points as follows (Volume 1, pp. 65-68). (1) There are a number of political parties within the U.K. which rely on and value contributions from those living overseas. (2) There is nothing intrinsically wrong with an overseas donation, provided that it does not come from a foreign government. (3) The 
impact of foreign donations has been exaggerated. (4) It is difficult to stipulate a satisfactory definition of the persons and corporations which must be treated as foreign, for the purpose of a legislative ban on foreign donations. (5) Concerning the upsurge of requirements for transparency and disclosure of political funding, this is not the time to introduce a further legislative restriction on the ability of political parties to secure adequate funding. (6) Two special cases: the treatment of some territories which come under the sovereignty of the U.K. and of future cross-border parties in Europe. This document presents, as well, the arguments in favor of a ban including the following four points: (1) Since political parties are involved in the domestic process taking place within the U.K., political parties should be confined to seeking financial support from those entitled to vote for them. (2) Disclosure is not enough. (3) Such difficulties as there may be with the legislative definition of a ban must be tackled, and the best solution possible produced. (4) Allowing donations from dependent territories would potentially open up a substantial loophole in the prohibition of foreign donations.

2 The first U.S. law banning foreign contributions to political campaigns was enacted in 1966. The amended Foreign Agents Registration Act (FARA) declared it a felony for a foreign principal to use an agent to contribute to domestic election campaigns or for a candidate to accept or solicit such contributions. The language of this prohibition, however, still permitted foreign nationals to provide funds directly to candidates. After this loophole was widely recognized through the Watergate hearings, Congress revised the Federal Election Campaign Act to prohibit contributions from any foreign national in 1974. Despite this revision, foreign money can still enter U.S. campaign treasuries through U.S. subsidiaries of foreign corporations. In general, U.S. law prohibits direct contributions from corporations to federal political campaigns, but U.S. corporations may establish political action committees (PACs), which have the right to make limited campaign contributions. Thus, a U.S.-incorporated, foreign-owned company's PACs could serve as a conduit for foreign funds to U.S. electoral campaigns, provided that they are registered with the Justice Department in accordance with the FARA (Damrosch, 1989; Powell, 1996). The definition of "foreign agent" in Gawande, Krishna, and Robbins (2004) and Kee, Olarreaga, and Silva (2004) refers to this type of PAC. Note that both papers use the gross amount of money for agents' activities in the U.S. as a variable for the extent of their presence in the U.S. political arena. In contrast, the amount of political donations to politicians has a key role in my research.

3 The home and the foreign countries have similar economic structures, so I don't refer to conditions for the foreign country explicitly in Sections 2,3 , and 6 in the text.

4 When the country is a net importer of good $i, \tau_{i}>0$ and $\tau_{i}<0$ mean an import tax and an 
import subsidy, respectively. When the country is a net exporter of good $i, \tau_{i}>0$ and $\tau_{i}<0$ denote an export subsidy and an export tax, respectively.

5 This model setting doesn't deal with the external effect. Externality does not change the results of this paper if welfare functions preserve concavity concerning $\tau$ and $\tau^{*}$. See Section 6, for an example.

${ }_{6} G^{N}$ is the function of $\tau$, with $\tau^{*}$ as given; the RP of the home country uses $\tau$ as a policy instrument, but it cannot manipulate a foreign country's policy instrument $\tau^{*}$ directly.

7 In the case of a small country, this assumption brings the result that free trade prevails in all sectors, as shown in Grossman and Helpman (1994), because the various SIGs neutralize one another. In the setting of this model, however, the results turn out to be different.

8 I focus on equilibrium where all SIGs make a positive amount of political contributions to the RP.

9 It is assumed that the rise in the tariff on good $i\left(\tau_{i}\right)$ increases its local price $\left(p_{i}\right)$ even though

it also leads to the rise in the other country's tariff $\left(\tau_{i}^{*}\right)$, which in turn decreases the home country's price of good $i\left(p_{i}\right)$. It is expressed as $0<\left(\partial p_{i} / \partial \tau_{i}\right)+\left.\left(\partial p_{i} / \partial \tau_{i}^{*}\right)\left(d \tau_{i}^{*} / d \tau_{i}\right)\right|_{R^{*}}$, or $\phi_{i}^{*}\left(d \tau_{i}^{*} / d \tau_{i}\right)_{R^{*}}<1-\phi_{i}$

10 The condition $\pi_{i}<1-\phi_{i}$ comes from the condition mentioned in footnote 8: $\pi_{i} \leq \phi_{i}^{*}\left(d \tau_{i}^{*} / d \tau_{i}\right)_{R^{*}}<1-\phi_{i}$, since $0<\varphi \leq 1$.

11 The model of multilateral lobbying presented in the text has enough applicability for the case of international SIGs. The role of international SIGs, organized by some SIGs in different countries, on the determination of trade policies was originally examined by Conconi (2003). In the context of my model, when some home and foreign SIGs form an international coalition and aim at maximizing an unweighted sum of their welfare by giving political contributions to both the home and foreign countries, the international SIG designs its donation to home and foreign RPs considering only the direct effect of home and foreign tariffs on its aggregate welfare, respectively. Again, strategic relationships between trade policies of the two countries disappear. Therefore, incorporating international SIGs into my model does not change the main argument in the text. 
12 Though mechanism design of international income redistribution is an important problem, it is outside of the scope of this paper.

13 It is possible for total externalities to have a more general form concerning the output of goods, as long as strong concavity of utility functions is preserved. If the reader interprets negative externalities as environmental pollution, it might be natural to consider that total externalities are the function of accumulated pollutants produced from past economic activities. The accumulation of externalities, however, is beyond the comparative static analysis.

14 When the country is an importer of good 1, this term means that the country has an incentive to decrease its import tariff so as to decrease the domestic price of good 1 and then reduce its domestic production. When the country is an exporter of good 1, on the other hand, this term shows the incentive to elevate its export tariff.

15 It is assumed that $\phi_{i}+\phi_{i}^{*} \neq 1$ in order to avoid the indetermination of equilibrium tariffs.

16 The derivation of first-order conditions in this part can be found in the Appendix. 